\title{
Histopathological Changes in the Gills Associated with Dactylogyrus spp. Infestation in Orange-spotted Grouper, Epinephelus coioides Reared in Sea Cages
}

\author{
Kurva Raghu Ramudu ${ }^{*}$, Saloni Shivam ${ }^{1}$, N. K. Sanil ${ }^{2}$, S. R. Krupesha Sharma ${ }^{2}$, \\ P. Vijayagopal ${ }^{2}$, P. P. Suresh Babu', A. Anuraj ${ }^{1}$, K. Navanath ${ }^{1}$, \\ B. Madhusudhana Rao $^{3}$ and Jayasree Loka ${ }^{1}$ \\ ${ }^{1}$ Karwar Research Centre of CMFRI, Karwar, India \\ ${ }^{2}$ Central Marine Fisheries Research Institute (CMFRI), Kochi, Kerala. \\ ${ }^{3}$ Central Institute of Fisheries Education, Mumbai, India \\ *Corresponding author
}

\section{A B S T R A C T}

\section{Keywords}

Orange spotted grouper, Cage culture,

Histopathology,

Flukes,

Dactylogyrus spp.

\section{Article Info}

Accepted:

10 July 2020

Available Online:

10 August 2020

\section{Introduction}

E. coioides is a potential species for mariculture in India. These are generally cultured in floating net cages or earthen ponds (FAO, 2010). It is also an important food fish for livelihoods of small and large-scale coastal fish farmers. Groupers are considered as a high-value species with a high market demand in foreign courtiers (FAO, 2010). At the same due to intensification or high stocking densities of E. coioides in cage culture cause stressful conditions and it may lead to expression of diseases in E. coioides. Fish under normal condition is in a state of equilibrium with its environment and infectious organisms. Any alterations in the environment, which will disturb equilibrium 
state, subsequently it may cause stress to the fish and they become more vulnerable to disease producing organism.

Disease is one of the major constraints to intensification of any culture. In improved farming systems, nursery operators have a tendency to overstock fish, which ultimately causes disease. High stocking densities of fry and fingerlings during nursery operation generally increases stress, and subsequently, fish become more susceptible to infectious disease (Snieszko, 1974).

Thousands of fish parasite species are already known and many more remain to be discovered. However very few are seriously harmful to their host. The presence of dense populations of fish kept in particular environmental conditions may favor certain parasites, necessary to cause harm to a fish, it varies considerably with the species and size of the fish and its health status (Ramudu, 2013). The major infectious agents are associated with gill, most of the pathogens are passing through gill and will enter into the host. Among the all parasites, monogenean parasites are the most important pathogens to cause severe stress in E. coioides, in addition to that reduce the growth and when it become more and more sevre, in the last stage it can be leads to moratlity, which will be resulted in serious economic losses in farmer. The disease caused by monogenean parasites, causes serious problems in aquaculture reported so many authors (Okamoto, 1963; Ogawa and Inouye, 1997; Yoshinaga et al., 2000, 2001, 2009; Mushiake et al., 2001; Nakayasu et al., 2002) with an obvious pathogenicity.

Various methods are used to assess the health status of aquatic organisms. Among them, the parasitological and histopathological diagnoses are presented as tools for analysis and prevention of diseases (Resende, 2009;
Sampaio et al., 2013). Histopathological study is a good indicator of fish health status, and the relevance of each lesion depends on how it affects organ function and the fish's ability to survive (Bernet et al., 1999). In this context, the present study focuses on histopathological investigations which have been proved to be a sensitive tool to detect histopathological changes in gill of $E$. coioides due to infestation of Dactylogyrus spp. parasites.

\section{Materials and Methods}

A total number of 15 freshly dead or ailing E.coioides (4.7-8.4cm length; 5.2-8.7g weight),) were collected from marine cages during the month of March, 2018 and transported to the laboratory for further analysis. Swabs were taken ascetically from kidney, spleen and liver and streaked onto Zobells marine agar (ZMA; Himedia, India), Thiosulfate Citrate Bile salt Sucrose agar (TCBS), Himedia, India) and brain heart infusion agar and incubated at $28{ }^{\circ} \mathrm{C}$ for $48 \mathrm{~h}$. Further, organs like gills, skin, fins, intestine and kidney were examined under microscope for the presence of parasites. Water temperature, salinity, $\mathrm{pH}$ were measured at weekly intervals using portable instruments. Ammonia $0.02 \mathrm{mg} / \mathrm{L}$, Nitrite $0.01 \mathrm{mg} / \mathrm{L}$ and Nitrate $0.01 \mathrm{mg} / \mathrm{L}$ ) was estimated according to procedure framed by APHA (1998). Representative samples of gills were fixed in $10 \% \mathrm{NBF}$, dehydrated in series of alcohol, cleared in xylene, embedded in paraffin wax and sectioned $(6 \mu)$ using a rotary microtome. The sections were stained with using Hematoxylin and Eosin, micro photographed (Roberts, 2001).

\section{Results and Discussion}

The infected fishes were lethargic, off feed, surfacing and with erratic swimming. Gills were pale in colour with excessive mucus. 
Liver and other internal organs were normal grossly. No bacteria could be grown on plates after an incubation at $28^{\circ} \mathrm{C}$ for 48 hours.

The present study revealed the presence of Dactylogyrus spp. in the gills of all the $E$. coioides examined. Dactylogyrus spp. were identified from the gill filaments of $E$. coioides with an overall prevalence of $100 \%$. The gill lesions are summarised in Table 1.

Briefly, the microscopy gill lesions showed severe morphological changes such as hyperplasia of secondary lamellae and their fusion, dilatation of the venous sinus at the middle of the primary lamellae, oedema (Figure 1B), complete loss of secondary lamellae due to attachment of parasite with marginal hooks (Figure 1C), vacuolation at the base of the primary lamellae (Figure 1D), telangiectasis of secondary lamellae (Figure
1E), and hypertrophy of the mucus cells and necrosis (Figure 1F). Curling of the secondary lamellae, degenerative and necrotic changes in the epithelium of gill filaments (Figure $2 \mathrm{~A}$ ), vacuole formation at the top of the secondary lamellae due to detachment of epithelial cells of secondary lamella (Figure 2B and F) were also observed in gill histology. Hypertrophy of the blood cells and vacuole formation at base of the secondary lamellae replacing the chloride cells was also observed (Figure 2C). Hyperplasia of secondary lamellar epithelial cells due to parasite attachment to the gill and dilatation of the venous sinus observed at the middle of the primary lamellae (Figure 2D). Oxygenated blood flow in to the primary lamellae and hypertrophy of blood cells and Hyperplasia of secondary lamellar epithelial cells (Figure 2E) has been found.

Table.1 Histopathological alterations of gill tissue due to Dactylogyrus spp. of E. coioides, the histopathological alterations were represented in symbol based on their severity.

\begin{tabular}{|l|c|c|}
\hline $\begin{array}{l}\text { Gill tissues morphological } \\
\text { Anomalies }\end{array}$ & $\begin{array}{c}\text { Normal gill } \\
\text { tissue }\end{array}$ & $\begin{array}{c}\text { Dactylogyrus spp. } \\
\text { infested gill tissue }\end{array}$ \\
\hline Lamellar fusion & - & ++ \\
\hline Completely Loss of Secondary lamella & - & ++ \\
\hline Gill lamellar hyperplasia & - & + \\
\hline $\begin{array}{l}\text { Degenerative and necrotic changes in the } \\
\text { epithelium of gill filaments }\end{array}$ & - & + \\
\hline Oedema & - & ++ \\
\hline Vacuolization in gill filament base & - & + \\
\hline $\begin{array}{l}\text { Haemorrhage at the base of the secondary } \\
\text { lamella }\end{array}$ & - & ++ \\
\hline Epithelial lifting & - & + \\
\hline Telangiectasis & - & + \\
\hline Blood congestion & - & + \\
\hline $\begin{array}{l}\text { Dilatation of the venous sinus, observed at the } \\
\text { Middle of the primary lamellae }\end{array}$ & - & + \\
\hline Hypertrophy of Mucus cells & - & + \\
\hline Hypertrophy of Blood cells & - & + \\
\hline Curling & - & + \\
\hline
\end{tabular}

Note: The anomalies visible in the gill morphology were divided based on the severity into three grades (-) no anomalies; (+) anomalies in $<20 \%$ of the fields; $(++)$ anomalies in $<20-60 \%$ of the fields. 
Figure.1 Photomicrographs of the gill tissue infested with Dactylogyrus spp. parasites (P); A. Photomicrographs of the normal gill tissue ( $\mathrm{H}$ and $\mathrm{E} ; 400 \mathrm{x})$ showing Gill filament with primary lamellae (PL) and Secondary lamellae (SL), Mucus cells (MC) and Chloride cells (CC); B. Dilatation of the venous sinus observed at the Middle of the primary lamellae (DVS); Oedema (ED), Complete fusion of secondary lamellae (FSL) (H and E;100x); C. Completely loss of secondary lamellae (LSL) due to attachment of parasite with marginal hooks $(\mathrm{MH})(\mathrm{H}$ and $\mathrm{E}$; 400x); D. Vacuole (VC) formation at base of the primary lamellae; with higher magnification showing secondary lamellar epithelial hyperplasia (HP) with secondary lamellar fusion (FSL) (H and E;400x); E. Telangiectasia of secondary lamellae (TG, H and E;400x); F. Hypertrophy of the Mucus cells (HT); Necrosis (N) observed at the apex of all secondary lamellae (H and E;400x).
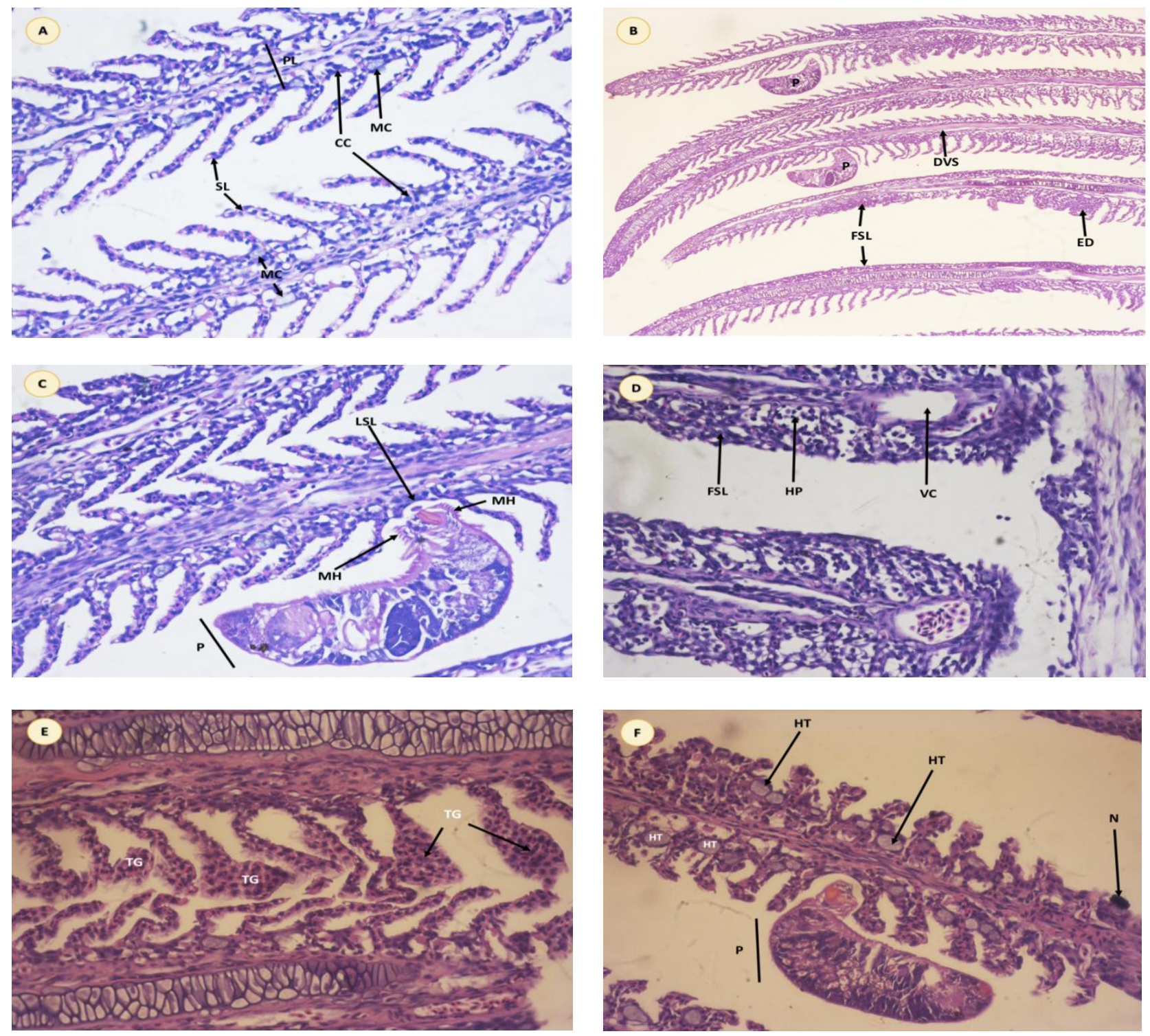
Fig.2 Photomicrographs of the gill tissue infested with Dactylogyrus spp. parasites (P); A. Curling of the secondary lamellae (CR) and Hypertrophy of the Mucus cells (HT), Degenerative and necrotic changes in the epithelium of gill filaments $(\mathrm{DN})(\mathrm{H}$ and E;400x); B. Gill lamellar hyperplasia (GLHP) and epithelial detachment (EDT)(H and E;400x); C. Hypertrophy of the blood cells (HT); Vacuole (VC) formation at base of the secondary lamellae in replace of Chloride cells, Completely loss of secondary lamellae (LSL) due to attachment of parasite with marginal hooks (MH) (H and E;400x). D. Hyperplasia (HP) of secondary lamellar epithelial cells due to parasite attachment to the gill and Dilatation of the venous sinus observed at the Middle of the primary lamellae (DVS) (H and E;400x). E. Oxygenated blood flow (OBF) in to the primary lamellae and hypertrophy (HT) of blood cells and Hyperplasia (HP) of secondary lamellar epithelial cells (H and E;400x). F. Vacuole (VC) formation at the top of the secondary lamellae due to detachment of epithelial (EDT) cells of secondary lamella
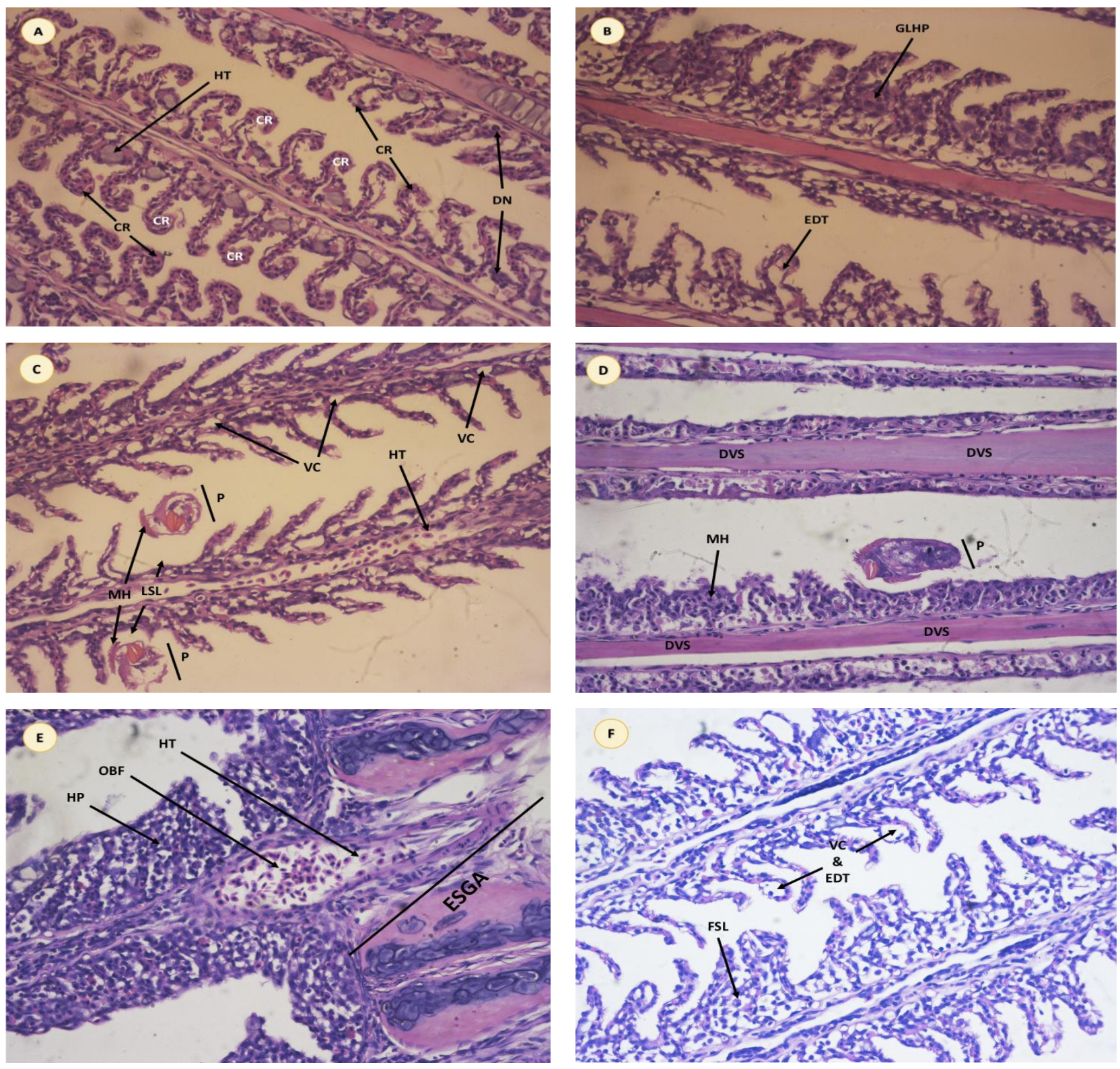
Histopathological study of the gills revealed a typical gill arch with complete loss of secondary lamellae due to attachment of parasite with marginal hooks. The parasite normally attaches to the gill lamellae of the host by inserting marginal hooklets (Turkayoztuk and Ahmet ozer, 2014) into the epithelium. Feeding activities of the parasites is associated with injuries to the epithelial cells of gill lamellae. The tissue alterations in the present study can be comparable to previous studies (Woo and Buchmann (2012) and Raissy and Ansari, 2011). Exacerbated swelling of gill arch with hyperplasia of secondary lamellar epithelial cells is due to parasite attachment to the gill, which is congruent with previous studies (Ramudu and Dash, 2015); Raissy and Ansari, 2011). The mucus cells of gill respond to the parasites with abnormal production of mucus and due to this hypertrophy of the mucus cells occurs as reported by Ramudu and Dash (2015) in Indian Major Carps and Jithendran et al., (2005) in the gill of Epinephelus tauvina due to monogenean infestation. Vacuole formation at base of the gills e secondary lamellae in the present study could be due to the absence or reduced numbers of chloride cells as appreciated by histopathology.

Parasitic infestations, especially those associated with Dactylogyrus spp., are the most devastating in nature affecting the morphology of the gills and physiological functions of the fish in general and gills in particular (Roberts, 2012).Present study revealed dilatation of the venous sinus at the middle of the primary lamellae. Similar abnormalities were found in Indian major caps with multiple infestation of parasites as reported by Ramudu and Dash (2015).

At the apex of secondary lamellae, gill exhibited necrosis which possibly leads to suffocation these were similar with Leong, (2001).Vacuole formation at base of the primary lamellae; with higher magnification showing secondary lamellar epithelial hyperplasia along with secondary lamellar fusion. In addition, telangiectasia were also observed in secondary lamellae of in gill histology, similar abnormalities in the gills were observed in fishes exposed to lead acetate in Cyprinus carpio reported by Mustafa et al., (2017) and Dezfuli et al., (2007) reported same anomalies in gill of European sea bass, Dicentrarchus labrax due infestation of Diplectanum aequans.

Curling of the secondary lamellae, Degenerative and necrotic changes in the epithelium of gill filaments, gill lamellar hyperplasia, vacuole formation at the top of the secondary lamellae due to detachment of epithelial cells of secondary lamella was observed in gill histology of E.coioides, similar anomalies were also observed in gills of Cyprinus carpio, here fishes were exposed to antimalarial drug chloroquine (CQ) studied by Ramesha et al., (2018).

It is concluded in the present study that most of the Dactylogyrus spp. (Gill flukes) were found on the gill filaments and lamellae of the E. coioides. Several histological alterations were observed in the gill, which was shown above. However, destruction of the gill filaments and lamellae has been recorded. Blood and mucus was feeding by the parasite and which leads to hyperplasia and destruction of the epithelial cells which leads to reducing the surface area for oxygen exchange for effective respiration. Such pathological changes can also cause severe stress in the fish, or can even lead to death due to lack of oxygen. Gill damage could result in loss of gill surface area for respiration, which would lead to suffocation particularly at high water temperatures in the early morning. The failure of osmoregulation is also an important issue, since the parasite piercing its marginal hooks in to the gill 
filaments and lamellae, finally exposes the surface of the gill to natural environment. According to the present study, the histopathological changes induced by the infestation of Dactylogyrus spp. would adversely affect the proper functioning of the gills of these infected fish.

\section{Acknowledgements}

This study was supported financially by ICAR-CMFRI, Kochi with the institutional funded project. Authors are grateful to the Director, CMFRI, Kochi for the kind support.

\section{References}

Bernet, D., Schimidt, H., Meier, W., Burkhardt-Holm, P., and Wahli, T. (1999). Histopathology in fish: proposal for a protocol to assess aquatic pollution. Journal of Fish Diseases, 22(1):25-34.

Dezfuli, B.S., Giari, L., Simoni, E., Menegatti, R., Shinn, A.P., and Manera, M. (2007). Gill histopathology of cultured European sea bass, Dicentrarchus labrax (L.), infected with Diplectanum aequans (Wagener 1857) Diesing 1958 (Diplectanidae: Monogenea). Parasitology Research, 2007; 100(4): 707-713.

FAO (2010). Cultured Aquatic Species Information Programme. Epinephelus coioides Retrieved from http://www.fao.org/fishery/culturedspec ies/Epinephelus_coioides/en.

Jithendran, K.P., Vijayan, K.K., Alavandi, S.V., and Kailasam, M. (2005). Benedeniae pinepheli (Yamaguti 1937), A Monogenean Parasite in Captive Broodstock of Grouper, Epinephelus tauvina (Forskal). Asian fisheries Science, 18: 121 -126.

Mushiake, K., Mori, K., and Arimoto, M. (2001). Epizootiology of anemia in wild
Japanese flounder. Fish Pathology, 36(3):125-32.

Mustafa, S.A., Al-Faragi, J.K., Salman, N.M., and Al-Rudainy, A.J. (2017). Histopathological alterations in gills, liver and kidney of common carp, Cyprinus carpio L. Exposed to lead Acetate. Advances in Animal and Veterinary Sciences, 5(9): 371-376.

Nakayasu, C., Yoshinaga, T., and Kumagai, A. (2002). Hematology of anemia experimentally induced by repeated bleeding in Japanese flounder with comments on the cause of flounder anemia recently prevailing in Japan. Fish Pathology, 37 (3):125-30.

Ogawa, K., and Inouye, K. (1997).Heterobothrium infection of cultured tiger puffer, Takifugurubripes (Teleostei: Tetraodontidae), a field study. Fish Pathology, 32 (1):15-20.

Okamoto, T. (1963). On the problems of monogenetic trematode infection of puffers from inland sea of Japan. Suisanzoshoku, 3:17-29.

Raissy, M., and Ansari, M. (2011). Histopathological changes in the gills of naturally infected Capoetaa culeata (Cuvier and Valenciennes, 1844) with parasites. African Journal of Biotechnology, 10(68):15422-15425.

Ramesha, M., Selvaraj, A., Rama Krishnan, P., and Shobanaa, C. (2018). Evaluation of acute and sublethal effects of chloroquine $(\mathrm{C} 18 \mathrm{H} 26 \mathrm{CIN} 3)$ on certain enzymological and histopathological biomarker responses of a freshwater fish Cyprinuscarpio, Toxicology Reports 5:18-27.

Ramudu, K.R. (2013). Parasitic study of Indian Major Carps in selected district of West Bengal, (MFSc Thesis). West Bengal University of Animal and Fishery Sciences, Kolkata, West Bengal, India.

Ramudu, K.R., and Dash, G. (2015). 
Histopathological alterations in the vital organs of Indian Major Carps with parasitic infestation in fish farms West Bengal, India. Drug Development and Therapeutics, 6(1):38-43.

Resende, E.K. (2009). Research in network in aquaculture: technological basis for sustainable development of aquaculture in Brazil. Revista Brasileira de Zootecnia-Brazilian Journal of Animal Science, 38: 52-57.

Roberts, R.J. (2001). Fish Pathology: The parasitology of teleost. W. B. Saunders, London, Pp. 254-296.

Roberts, R.J. (2012). Fish Pathology: The parasitology of teleost. Blackwell Publishing Ltd., UK, 295.

Sampaio, F.G., Losekann, M.E., Luiz, A.J.B., Neves, M.C., Frascá-Scorvo, C.M.D., and Rodrigues, G.S. (2013). Environmental monitoring and management of fish farming in cages in reservoirs - Monitoramento e gestãoambiental da pisciculturae mtanquesredeem reservatórios. Informe Agropecuário, Belo Horizonte, 34:1-11.

Snieszko, S.F. (1974). The effect of environmental stress on outbreak of infectious diseases of fishes, Journal of Fish Biology 6 (2): 197-208.

Turkayoztuk and Ahmet O. (2014).
Monogenean Fish Parasites, Their Host Preferences and Seasonal Distributions in the Lower Kizilırmak Delta (Turkey). Turkish Journal of Fisheries and Aquatic Sciences, 14: 367-378.

Woo, P.T.K., and Buchmann, K. (2012). Fish parasites : Pathobiology and protection. Cambridge, USA, (C) CAB International, 1-371.

Yoshinaga, T., Kamaish, T., Segawa, I., Kumagai, A., Nakayasu, C., Yamano, K., Sorimachi, M. (2000) Hematology, histopathology and the monogenean Neoheterobothrium hirame infection in anemic flounder. Fish Pathology, 35 (3):131-6.

Yoshinaga, T., Kamaishi, T., Segawa, I., Yamano, K., Ikeda, H., and Sorimachi, M. (2001). Anemia caused by challenges with the monogenean Neoheterobothrium hirame in the Japanese flounder. Fish Pathology, 36(1):13-20.

Yoshinaga, T., Tsutsumi, H.K., and Ogawa, K. (2009). Origin of the diclidophorid monogenean Neoheterobothrium hirame Ogawa, 1999, the causative agent of anemia in olive flounder Paralichthys olivaceus. Fishery Science, 75(5):1167-1176.

\section{How to cite this article:}

Kurva Raghu Ramudu, Saloni Shivam, N. K. Sanil, S. R. Krupesha Sharma, P. Vijayagopal, P. P. Suresh Babu, A. Anuraj, K. Navanath , B. Madhusudhana Rao and Jayasree Loka. 2020. Histopathological Changes in the Gills Associated with Dactylogyrus spp. Infestation in Orange-spotted Grouper, Epinephelus coioides Reared in Sea Cages. Int.J.Curr.Microbiol.App.Sci. 9(08): 01-08. doi: https://doi.org/10.20546/ijcmas.2020.908.001 